\section{Risk factors for bad obstetric history in Kirkuk women, Iraq}

\author{
Aljumaili ZKM,1,2 Alsamarai AM3,4
}

${ }^{1}$ Department of Microbiology, Tikrit University College of Medicine, Tikrit, Iraq ${ }^{2}$ Kirkuk Health Authority, ${ }^{3}$ Departments of Medicine and Microbiology, Tikrit University College of Medicine, Tikrit, Iraq, ${ }^{4}$ Asthma, Allergy Centre, Tikrit Teaching Hospital, Tikrit, Iraq

*Correspondence to: Dr. Zainab Khalil Aljumaili, Departments of Microbiology, Tikrit University College of Medicine, Tikrit, Iraq, email: galsamarrai@ yahoo.com, galsamarrai@hotmail.com

\begin{abstract}
INTRODUCTION: Microbial agents such as Toxoplasma, rubella, CMV and HSV are important cause of infections during pregnancy, which mainly are asymptomatic. However, the infection during pregnancy may result in serious foetal side effects. Objective was to determine the risk factors that enhance the development of bad obstetric history (BOH) due to TORCH infections in Iraqi women.
\end{abstract}

MATERIALS AND METHODS: A 538 women were included in the study, of them 293 (54.5\%) were with $\mathrm{BOH}$, and $245(45.5 \%)$ were with normal pregnancy history. In the BOH group, 144 (49.1\%) women were pregnant, while in the normal pregnancy group, 117 (47.7\%) were pregnant. Logistic regression analysis was used to determine the risk factors that may play a role in development of BOH.

RESULTS: Multifactorial analysis indicated that Toxoplasma gondii IgM, rubella IgM, rubella IgG, CMV IgM, HSV -2 IgG and animal exposure were risk factors that lead to $\mathrm{BOH}$ development. However, Toxoplasma IgG seropositivity had inverse correlation to $\mathrm{BOH}$ development. Mother education was a significant protective $(\mathrm{OR}=0.614$, $\mathrm{p}=<0.001$ ) factor that reduce development of $\mathrm{BOH}$. Residence, education, occupation and family size influenced the role of TORCH in induction of $\mathrm{BOH}$.

CONCLUSIONS: This study indicated that Toxoplasma gondii IgM, rubella IgM, rubella IgG, CMV IgM, HSV-2 IgG and animal exposure were risk factors that lead to $\mathrm{BOH}$ development. Mother education was a significant protective factor that reduce development of $\mathrm{BOH}$.

KEY WORDS: BOH, CMV, HSV, Rubella, Toxoplasma, Iraq

Article submitted 10 January. Reviewed 20 February. Author correction 20 August. Final version accepted 27 August 2013. 


\section{INTRODUCTION}

Microbial agents such as Toxoplasma, rubella, CMV and HSV are important cause of infections during pregnancy. These infections often lead to mild or asymptomatic infection in the mother. ${ }^{1}$ However, the infection during pregnancy may result in serious congenital abnormalities, intrauterine growth retardation and may cause foetal death . 2 Bad obstetric history (BOH) implies previous unfavorable foetal outcome in terms of two or more consecutive spontaneous abortions, history of intrauterine foetal death, intrauterine growth retardation, stillbirth, early neonatal death, and/or congenital anomalies ${ }^{2}$ The causes of $\mathrm{BOH}$ may be genetic, hormonal, abnormal maternal immune response, and maternal infection. ${ }^{3,4}$ The prenatal and perinatal infections, falling under the designation of TORCH complex, are a medical acronym for a set of perinatal infections, i.e., infections that are passed from a pregnant woman to her fetus. ${ }^{5}$

Most of the TORCH infections cause mild maternal morbidity but have serious foetal consequences. ${ }^{6}$ The ability of the fetus to resist infectious organisms is limited and the foetal immune system is unable to prevent the dissemination of infectious organisms to various tissues. ${ }^{6}$ An attempt is being made in reported work to find out the correlation of TORCH infection during pregnancy in the Iraqi population. ${ }^{7}$ However, all of these works presented their findings as frequency of IgM and/or IgG in women with $\mathrm{BOH}$ compared to control. The present study is the first one that is performed in Iraq which evaluates the association between TORCH agent's infection and $\mathrm{BOH}$ development using multifactorial analysis. The objective of the study is to determine the risk factors of $\mathrm{BOH}$ due to TORCH infections in Iraqi women.

\section{MATERIALS AND METHODS}

\section{Study Population}

This descriptive case-control study was conducted at the antenatal clinic of Kirkuk General Hospital and Primary Health Care Centre in Tessean. Women (Pregnant or Non pregnant) with bad obstetric history were recruited from those attending outpatient Gynaecology Clinic, Kirkuk General Hospital or the outpatient Clinic at Tessean PHC. The study population was divided into two group, the women with bad obstetric history $(n=293)$ and women with previous normal pregnancy $(n=245)$. Concerning residence, the study population categorized into urban $(n=398)$ or rural area $(n=140)$ living women, while according tooccupation the women divided into house wife $(\mathrm{n}=497)$ or working $(n=41)$ women. In regard to education the study population was categorized into uneducated $(n=34)$, primary $(n=331)$, secondary $(n=105)$, and college and above $(\mathrm{n}=68)$ education. In addition, according to crowding index the women divided into those with crowding index of 3 and less $(n=478)$ and those with that above $3(n=60)$. The demographic information of these groups is shown in Table 1. The target number recruited for each group was 150 women. However, the total number of women included in the study was 538, of them 293 (54.5\%) were with BOH, and 245 (45.5\%) were with normal pregnancy history. In the BOH group, 144 (49.1\%) women were pregnant, while in the normal pregnancy group, 117 (47.7\%) were pregnant.

\section{Collection of data}

The designated investigators visited the outpatient department daily, selected the study subjects, and screened them using a predesigned pretested schedule considering the inclusion and exclusion criteria till the study subject's was identified. The next available age-matched multiparous antenatal woman without $\mathrm{BOH}$ was included in the control group subjects. Clinical examination and laboratory investigations were carried out for the study subjects to exclude other causes of foetal wastage, such as hypertension, diabetes mellitus, syphilis, $\mathrm{Rh}$ (rhesus) incompatibility, physical causes of abortion, and consanguinity. Subjects with known causes of foetal wastage are to be excluded from the study. All of them were interviewed to ascertain age, medical and obstetric information.

\section{Sample Collection and testing}

For serological analysis, 5-10 mL of venous blood was collected in a sterile container with strict aseptic precautions from each study subjects. The serum was separated and stored in numbered aliquots at $-20^{\circ} \mathrm{C}$ till assayed. All the serum samples collected from the study and control groups were tested for Toxoplasma, Rubella, CMV and HSV-2 IgM and IgG antibodies by commercially- available (ELISA) kits. ELISA test was performed according to manufacturer instructions. The kit purchased from BioCheck, Inc, 323 Vintage Park Dr, Foster City, CA 94404. The results was read by a Microwell reader and compared in a parallel manner with controls; optical density was read at $450 \mathrm{~nm}$ on an ELISA reader. 


\section{Analysis of data}

Collected data were compiled in Microsoft Excel spread sheet. The proportion and the mean value were computed in appropriate situations. To find out any association between categorical data, Chi square test was employed using the SPSS (Version 16). The categorical data were presented as frequency \pm SD and 95\% Confidence Interval. The determinants for Toxoplasma, Rubella, CMV and HSV-2 infections are determined by calculation of Odds ratio using multiple logistic regression line analysis. The calculation performed as comparison between women with $\mathrm{BOH}$ and women with previous normal pregnancy.

\section{Ethical approval}

The purpose and procedures of the study were explained to all the study subjects, and informed consent was obtained from them. The study design was approved by the ethical committee of TUCOM.

\section{RESULTS}

Multifactorial analysis indicated that Toxoplasma gondii $\operatorname{IgM}(\mathrm{OR}=9.36, \mathrm{p}=0.01)$, rubella $\mathrm{IgM}(\mathrm{OR}=3.23$, $\mathrm{p}=0.02)$, rubella $\operatorname{IgG}(\mathrm{OR}=7.321, \mathrm{p}=0.000), \mathrm{CMV} \operatorname{IgM}$ (OR=19.668, p=0.009), HSV-2 IgG (OR=7.569, $\mathrm{p}=0.000)$ and animal exposure $(\mathrm{OR}=2.007, \mathrm{p}=0.008)$ were risk factors that lead to $\mathrm{BOH}$ development,(Tables 1\& 2). However, Toxoplasma IgG seropositivity had inverse correlation $(\mathrm{OR}=0.56$, $\mathrm{p}=0.009$ ) to $\mathrm{BOH}$ development. Mother education was a significant protective (OR=0.614, $\mathrm{p}=0.000$ ) factor that reduce development of $\mathrm{BOH}$.

Residence significantly influence the development of $\mathrm{BOH}$ in acute T. gondii (OR=11.67, $\mathrm{p}=0.02)$, acute CMV (OR=1.377, $\mathrm{p}=0.02)$, remote CMV $(\mathrm{OR}=17.58, \mathrm{p}=0.04)$ infections, (Table 3). Furthermore, housewife was a significant risk factor for $\mathrm{BOH}$ development in pregnant women infected with rubella $(\mathrm{OR}=22.57, \mathrm{p}<0.0001)$, (Table 4).

Mother education was a significant factor that influenced the association between $\mathrm{BOH}$ development and presence of $T$. gondii IgG (OR= 2.124, $\mathrm{p}=0.03)$, Rubella IgM $(\mathrm{OR}=8.584$, $\mathrm{p}<0.0001)$, rubella $\operatorname{IgG}(\mathrm{OR}=10.873, \mathrm{p}<0.0001)$, CMV IgM (OR=21.781, $\mathrm{p}<0.0001)$, CMV IgG (OR= 13.898, $\mathrm{p}<0.0001)$ and HSV -2 IgG $(\mathrm{OR}=2.7169$, $\mathrm{p}=0.0002)$, (Table 5).

Crowding index act as a risk factor for influence of development of $\mathrm{BOH}$ due to rubella current infection $(\mathrm{OR}=3.302, \mathrm{p}=0.025)$, rubella remote infection (OR=7.321, p=0.000), CMV current infection (OR=19.668, p=0.0009) and $\mathrm{HSV}-2$ latent infection (OR=7.569, $\mathrm{p}=0.000)$, (Table 6).

Pregnancy is a risk factor that influence development of bad obstetric outcome due to infection of pregnant women with remote/ latent Toxoplasma (OR=2.32, $\mathrm{p}=<0.0001)$, current rubella (OR=19.229, $\mathrm{p}=0.004)$, current CMV $(\mathrm{OR}=3.15, \mathrm{p}=0.004)$ and remote/latent $\mathrm{CMV}$ (OR=3.14, $\mathrm{p}=0.01$ ) infections, (Table 7).

\section{DISCUSSION}

In multifactorial analysis, development of $\mathrm{BOH}$ was associated with T.gondii IgM, rubella IgG, rubella IgM, CMV IgM, HSV-2 IgG seropositivity, and animal exposure. This association was reported for other geographical areas in Iraq as an IgG seroprevalence 7 in contrast to other

Table 1. Risk factors for bad obstetric history in relation to toxoplasma, rubella, CMV and HSV-2 infections using multivariate analysis

\begin{tabular}{|c|c|c|c|c|c|}
\hline \multirow[t]{2}{*}{ Variable } & \multicolumn{2}{|c|}{ Positive number (\%) } & \multirow{2}{*}{ Odd Ratio } & \multirow{2}{*}{ P Value } & \multirow{2}{*}{$\begin{array}{l}95 \% \text { Confidence } \\
\text { Interval }\end{array}$} \\
\hline & $\begin{array}{l}\text { Patients } \\
\text { (Total No.) } \\
(293)\end{array}$ & $\begin{array}{l}\text { Control } \\
\text { (Total No.) } \\
\text { (245) }\end{array}$ & & & \\
\hline Toxoplasma gondii IgM & $5(1.7)$ & $0(0)$ & 9.36 & $<0.05$ & $0.52-170.13$ \\
\hline Toxoplasma gondii IgG & $79(27)$ & $77(31.4)$ & 0.56 & 0.009 & $0.36-0.86$ \\
\hline Rubella IgM & $5(1.7)$ & $13(5.3)$ & 3.23 & 0.02 & $1.13-9.18$ \\
\hline Rubella IgG & $261(89.1)$ & 71) & 7.321 & 0.000 & $3.88-13.77$ \\
\hline Cytomegalo virus IgM & $21(7.2)$ & $13(5.3)$ & 19.668 & 0.009 & $2.09-186.11$ \\
\hline Cytomegalo virus IgG & $283(96.6)$ & $232(94.7)$ & 0.378 & NS & $0.095-1.515$ \\
\hline Herpes simplex Virus 2 IgM & $17(3.8)$ & $0(0)$ & 0.000 & NS & 0.000 \\
\hline Herpes simplex Virus 2 IgG & $101(34.5)$ & $29(11.8)$ & 7.569 & 0.000 & $4.24-13.52$ \\
\hline
\end{tabular}


Table 2. Risk factors for bad obstetric history in relation to demographic characteristics and animal exposure using multivariate analysis

\begin{tabular}{|c|c|c|c|c|c|c|c|}
\hline Variable & & $\begin{array}{l}\text { Women with } \\
\text { Bad } \\
\text { Obstetric } \\
\text { History } \\
\end{array}$ & Control & $\begin{array}{l}\text { Odd } \\
\text { Ratio }\end{array}$ & P Value & $\begin{array}{l}95 \% \\
\text { Confidence } \\
\text { Interval }\end{array}$ & \\
\hline \multirow[t]{2}{*}{ Residence } & Urban (398) & 214 & 184 & \multirow[t]{2}{*}{0.988} & \multirow[t]{2}{*}{ NS } & 0.654 & \multirow[t]{2}{*}{-} \\
\hline & Rural (140) & 79 & 61 & & & 1.493 & \\
\hline Occupation & $\begin{array}{l}\text { Housewife (497) } \\
\text { Working (41) }\end{array}$ & $\begin{array}{l}265 \\
28\end{array}$ & $\begin{array}{l}232 \\
13\end{array}$ & 1.952 & NS & $\begin{array}{l}0.970 \\
3.928\end{array}$ & - \\
\hline Crowding Index & $\begin{array}{l}\leq 3 \quad(478) \\
>3 \quad(60)\end{array}$ & $\begin{array}{l}258 \\
35\end{array}$ & $\begin{array}{l}229 \\
16\end{array}$ & 0.993 & NS & $\begin{array}{l}0.846 \\
1.165\end{array}$ & - \\
\hline Animal & $\begin{array}{l}\text { Present }(90) \\
\text { Absent }(448)\end{array}$ & $\begin{array}{l}61 \\
232\end{array}$ & $\begin{array}{l}29 \\
216\end{array}$ & 2.007 & 0.008 & $\begin{array}{l}1.195 \\
3.373\end{array}$ & - \\
\hline Education & $\begin{array}{l}\text { Uneducated (34) } \\
\text { Primary (331) } \\
\text { Secondary (105) } \\
\text { College (68) }\end{array}$ & $\begin{array}{l}21 \\
202 \\
44 \\
26\end{array}$ & $\begin{array}{l}13 \\
129 \\
61 \\
42\end{array}$ & 0.614 & 0.000 & $\begin{array}{l}0.498 \\
0.758\end{array}$ & - \\
\hline Age in years & $\begin{array}{l}<30(312) \\
\geq 30(226)\end{array}$ & $\begin{array}{l}172 \\
121\end{array}$ & $\begin{array}{l}142 \\
103\end{array}$ & 0.997 & NS & $\begin{array}{l}0.977 \\
1.018\end{array}$ & - \\
\hline
\end{tabular}

Table 3. IgM and IgG TORCH agents as risk factors for BOH development complex in relation to residence (Urban vs. rural)

\begin{tabular}{|c|c|c|c|c|c|}
\hline \multirow[t]{3}{*}{ Organism } & \multirow[t]{3}{*}{ Variable } & \multicolumn{2}{|c|}{ Residence (Total No.) } & \multirow{3}{*}{$\begin{array}{l}\text { Odd ratio }(95 \% \\
\text { Confidence interval) }\end{array}$} & \multirow[t]{3}{*}{ P value } \\
\hline & & \multicolumn{2}{|c|}{ Number positive } & & \\
\hline & & $\begin{array}{l}\text { Urban } \\
\text { (398) }\end{array}$ & $\begin{array}{l}\text { Rural } \\
(140)\end{array}$ & & \\
\hline \multirow[t]{2}{*}{ Toxoplasma } & IgM & 1 & 4 & $11.67(1.29-105.23)$ & 0.02 \\
\hline & IgG & 128 & 28 & $0.53(0.33-0.84)$ & 0.006 \\
\hline \multirow[t]{2}{*}{ Rubella } & IgM & 18 & 0 & $0.073(0.0044-1.223)$ & NS \\
\hline & IgG & 315 & 120 & $1.58(0.929-2.690)$ & NS \\
\hline \multirow[t]{2}{*}{ Cytomegalovirus } & IgM & 34 & 0 & $1.377(1.0023-1.6175)$ & 0.02 \\
\hline & IgG & 375 & 140 & $17.58(1.061-291-484)$ & 0.04 \\
\hline \multirow[t]{2}{*}{ Herpes simplex virus 2} & IgM & 15 & 2 & $0.37 \quad(0.0835-1.639)$ & NS \\
\hline & IgG & 97 & 33 & $0.957(0.6088-1.5046)$ & NS \\
\hline
\end{tabular}

studies in regards to CMV IgG, ${ }^{3}$ HSV IgM. 3,7

However, an inverse association was demonstraed between $\mathrm{BOH}$ development and education level, a finding consistent to other studies finding. 8-10 Unexpectedly, our cohort were about half as likely as seronegative patients to have $T$. gondii IgG antibodies ( $\mathrm{OR}=0.56)$, indicating inverse association between seropositivity and $\mathrm{BOH}$ development. Two studies performed in Baghdad, Iraq reported same association. ${ }^{7}$ Transmission of the infection to the foetus usually occurs when primary infection is acquired by an immunologically normal mother during gestation. ${ }^{11}$ IgM seropositivity indicates acute/early infection, while remote infection is usually indicated by a negative IgM with a positive IgG test result. ${ }^{12}$ Our women study population who were $T$. gondii IgG seropositive, all are negative for IgM and thus all are remote infection, which leads to low rate of foetal transmission. Consequently, this concert outcome was low rate of $\mathrm{BOH}$ and no association between $T$. gondii IgG seropositivity and $\mathrm{BOH}$ development. This explanation was confirmed 
Table 4. IgM and IgG TORCH agents as risk factors for $\mathrm{BOH}$ development complex in relation to Occupation (Housewife vs. working)

\begin{tabular}{|c|c|c|c|c|c|}
\hline \multirow[t]{3}{*}{ Organism } & \multirow[t]{3}{*}{ Variable } & \multicolumn{2}{|c|}{ Occupation (Total No.) } & \multirow{3}{*}{$\begin{array}{l}\text { Odd ratio } \\
\text { Confidence interval) }\end{array}$} & \multirow[b]{3}{*}{$P$ value } \\
\hline & & \multicolumn{2}{|c|}{ Number positive } & & \\
\hline & & $\begin{array}{c}\text { Housewife } \\
\text { (497) }\end{array}$ & $\begin{array}{r}\text { Working } \\
\text { (41) }\end{array}$ & & \\
\hline \multirow[t]{2}{*}{ Toxoplasma } & IgM & 5 & 0 & $0.926(0.0504-17.0558)$ & NS \\
\hline & IgG & 149 & 7 & $2.079(0.9016-4.7972)$ & NS \\
\hline \multirow[t]{2}{*}{ Rubella } & IgM & 18 & 0 & $3.202(0.189-54.097)$ & NS \\
\hline & IgG & 409 & 26 & $22.57(9.69-52.58)$ & $<0.0001$ \\
\hline \multirow[t]{2}{*}{ Cytomegalo virus } & $\operatorname{IgM}$ & 34 & 0 & $6.178 \quad(0.372-102.603)$ & NS \\
\hline & IgG & 474 & 41 & $0.2433(0.0145-4.0777)$ & NS \\
\hline \multirow[t]{2}{*}{ Herpes simplex virus 2} & IgM & 16 & 1 & $1.3306(0.172-10.293)$ & NS \\
\hline & IgG & 115 & 15 & $0.5218(0.2673-1.0185)$ & NS \\
\hline
\end{tabular}

Table 5. IgM and IgG TORCH agents as risk factors for BOH development complex in relation to education (uneducated, primary, secondary, college and above)

\begin{tabular}{|c|c|c|c|c|c|}
\hline \multirow[t]{2}{*}{ Organism } & \multirow[t]{2}{*}{ Variable } & \multicolumn{2}{|c|}{$\begin{array}{l}\text { Education (Total No.) } \\
\text { Positive number }\end{array}$} & \multirow[t]{2}{*}{$\begin{array}{l}\text { Odd ratio } \\
\text { Confidence interval) }\end{array}$} & \multirow[t]{2}{*}{ P value } \\
\hline & & $\begin{array}{c}\text { Uneducated } \\
\text { (34) }\end{array}$ & $\begin{array}{c}\text { Educated } \\
(504)\end{array}$ & & \\
\hline \multirow[t]{2}{*}{ Toxoplasma } & IgM & 0 & 5 & $1.6187(0.0885-29.6013)$ & NS \\
\hline & IgG & 11 & 145 & $2.1244(1.0534-4.2843)$ & 0.03 \\
\hline \multirow[t]{2}{*}{ Rubella } & IgM & 1 & 17 & $8.5842(4.0193-18.3339)$ & $<0.0001$ \\
\hline & IgG & 17 & 418 & $10.8727(4.553-25.9666)$ & $<0.0001$ \\
\hline \multirow[t]{2}{*}{ Cytomegalo virus } & IgM & 5 & 29 & $21.9818(7.550-63.9966)$ & $<0.0001$ \\
\hline & IgG & 34 & 481 & 13.8981 (7.838-24.6412) & $<0.0001$ \\
\hline \multirow[t]{2}{*}{ Herpes simplex virus 2} & IgM & 4 & 13 & $0.4235(0.0553-3.2458)$ & NS \\
\hline & $\operatorname{IgG}$ & 4 & 126 & $2.7169(1.6013-4.6090)$ & 0.0002 \\
\hline
\end{tabular}

Table 6. IgM and IgG TORCH agents as risk factors for BOH development complex in relation to Crowding Index $(\leq 3$ or $>3)$

\begin{tabular}{|c|c|c|c|c|c|}
\hline \multirow[t]{2}{*}{ Organism } & \multirow[t]{2}{*}{ Variable } & \multicolumn{2}{|c|}{$\begin{array}{l}\text { Crowding index } \\
\text { (Total No.) } \\
\text { Number positive }\end{array}$} & \multirow[t]{2}{*}{$\begin{array}{l}\text { Odd ratio }(95 \% \\
\text { Confidence interval) }\end{array}$} & \multirow[t]{2}{*}{ P value } \\
\hline & & $\begin{array}{c}\leq 3 \\
(478)\end{array}$ & $\begin{array}{c}>3 \\
(60)\end{array}$ & & \\
\hline \multirow[t]{2}{*}{ Toxoplasma } & IgM & 5 & 0 & $0.6645(0.3131-1.4101)$ & NS \\
\hline & IgG & 141 & 15 & $0.56(0.363-0.863)$ & NS \\
\hline \multirow[t]{2}{*}{ Rubella } & IgM & 18 & 0 & 3.302 (1.106-5.8139) & 0.025 \\
\hline & IgG & 378 & 57 & $7.321(3.889-13.779)$ & 0.000 \\
\hline \multirow{2}{*}{ Cytomegalo virus } & IgM & 29 & 5 & $19.668(2.079-186.112)$ & 0.0009 \\
\hline & IgG & 456 & 59 & $0.378(0.095-1.515)$ & NS \\
\hline \multirow[t]{2}{*}{ Herpes simplex virus 2} & IgM & 6 & 9 & 0.015 & NS \\
\hline & IgG & 126 & 4 & $7.569(4.237-13.522)$ & 0.000 \\
\hline
\end{tabular}


Table 7. Pregnancy as risk factor for development of TORCH infections (pregnant vs. non pregnant)

\begin{tabular}{|c|c|c|c|c|c|}
\hline \multirow[t]{2}{*}{ Organism } & \multirow[t]{2}{*}{ Variable } & \multicolumn{2}{|c|}{ Pregnancy (Total No.) } & \multirow{2}{*}{$\begin{array}{l}\text { Odd ratio (95\% Confidence } \\
\text { interval) }\end{array}$} & \multirow[t]{2}{*}{ P value } \\
\hline & & $\begin{array}{l}\text { Pregn } \\
\text { ant } \\
(261)\end{array}$ & $\begin{array}{l}\text { Non- } \\
\text { pregnant } \\
(277)\end{array}$ & & \\
\hline \multirow[t]{2}{*}{ Toxoplasma } & IgM & 4 & 1 & $0.2328(0.0258-2.0966)$ & NS \\
\hline & IgG & 53 & 103 & $2.3231(1.5765-3.4234)$ & $\begin{array}{l}<0.000 \\
1\end{array}$ \\
\hline \multirow[t]{2}{*}{ Rubella } & IgM & 17 & 1 & $19.2295(2.540-145.563)$ & 0.004 \\
\hline & IgG & 206 & 229 & $0.7851(0.5105-1.2074)$ & NS \\
\hline \multirow[t]{2}{*}{ Cytomegalo virus } & IgM & 25 & 9 & $3.1544(1.4435-6.8933)$ & 0.004 \\
\hline & IgG & 244 & 271 & 3.1469 (1.2211 - 8.1097) & 0.01 \\
\hline \multirow[t]{2}{*}{ Herpes simplex virus 2} & IgM & 8 & 9 & $0.9416(0.3577-2.4783)$ & NS \\
\hline & IgG & 57 & 73 & $0.7808(0.5249-1.1615)$ & NS \\
\hline
\end{tabular}

OR for T. gondii - IgM seropositivity and $\mathrm{BOH}$ development (OR=9.36, $\mathrm{p}=0.01)$.

Residence significantly influence the development of $\mathrm{BOH}$ in acute $T$. gondii $(\mathrm{OR}=11.67, \mathrm{p}=0.02)$ and $\mathrm{CMV}$ $(\mathrm{OR}=1.377, \mathrm{p}=0.02)$, in addition, remote $\mathrm{CMV}$ infection (OR=17.58, $\quad \mathrm{p}=0.04)$. Furthermore, housewife occupation was a significant risk factor for $\mathrm{BOH}$ development in pregnant women infected with rubella $(\mathrm{OR}=22.57, \mathrm{p}<0.0001)$.

Crowding index act as a risk factor for influence of development of $\mathrm{BOH}$ due to rubella current infection and remote infection, CMV current infection and HSV2 latent infection. Nevertheless, data from studies reported previously for Iraq ${ }^{7}$ and our study indicate that a significant seroimmunity gap (i.e. an absence of detectable protective IgG antibodies) with range from $19.1 \%$ to $91 \%$, which exists in the upper socioeconomic sector of the population. ${ }^{13}$ Lower findings of a $5-18.4 \%$ serological gap were reported in literature for Africa, India, Nepal, Iran, Italy.,14-17 The worryingly wide seroimmunity gap in women from upper socio-economic strata was also evident in several global published studies. ${ }^{14}$ The immunity gap in upper socio-economic group women largely reflects better living standards and less crowding. However, the waning of rubella IgG antibodies titer overtime may influence and well aggravate the situation, as the developed immunity protection against rubella infection reduced with time.

This could be enough to reduce the circulation of wildtype virus sufficiently to create a significant immunity gap in adolescent and young women in this population and thus the acquired immunity is not protective, under the effect of avidity and affinity characters of antibody. This may be an explanation for the influence of crowding index as risk factor for the development of $\mathrm{BOH}$ due to rubella infection in women with positive IgG.

Both bivariate and multifactorial analysis indicated a positive association between HSV-2 IgG seroprevalence and development of adverse pregnancy outcome in pregnant women. Theoretically, the presence of IgG seems to provide a protective for new infection, but as this study indicated the situation is different, as illustrated by high rate of $\mathrm{BOH}$ development in the presence of HSV-2 IgG. Primary genital infections may be caused by types 1 or 2, although HSV 2 infections are most likely to cause genital recurrences. ${ }^{18}$ Previous studies have shown that concurrent oral and genital infections with an identical HSV strain may occur in the same person and that prior oral herpes caused by HSV 1 fails to prevent subsequent genital infection with HSV 2. Nevertheless, exogenous reinfection with either HSV 1 or HSV 2 in patients with recurrent genital herpes is considered to be uncommon. ${ }^{19}$

It was previously identified that a majority of HSV-2 reactivations last less than a day ${ }^{20}$, however recent findings ${ }^{21}$ demonstrate that the cardinal feature of HSV-2 shedding is extraordinary episode heterogeneity. Longer and higher copy number episodes, which often manifest with genital lesions, are notable for multiple erratic peaks and wide viral dispersion. Viral loads are stable over periods of minutes but 
can change dramatically over hours. HSV-2 expansion and decay phases in mucosa are considerably more rapid and complex than those of HIV and hepatitis B, which have been characterized by sampling plasma. ${ }^{22}$ For disseminated infections, sampling from blood may reflect true host-pathogen dynamics due to homogeneous mixing of viruses and PBMCs, which originate from thousands of infectious foci. However, many infections are confined to small anatomic regions (e.g. HSV); localized host-pathogen interactions within specific organ tissue constitutes the predominant site of pathogenesis, and measurements of viral replication and immune response are not accurately reflected in the blood compartment. Moreover, sampling of infected tissue often reveals that the density of virus and host immune cells differ enormously across small distances. Spatial features of infection are a critical, and relatively unexplored, component of viral dynamics. ${ }^{21}$

Schniffer et al data suggest intensely localized competition between HSV-2 and the immune system in genital mucosa. ${ }^{21}$ The possibility that by rapidly spreading between epidermal cells, HSV-2 ensures high viral production within a single ulcer, despite an intense local immune response. ${ }^{23}$ Cell-free HSV-2 may prolong episodes via spread to contiguous sites where immune cell density is lower. Each episode is contained by the mucosal immune system, and HSV-2 is often asymptomatic in immunocompetent hosts. Viral strategies that lead to repeated episodes, rapid episode expansion and frequent re-expansion, allow for high shedding frequency, thereby enhancing transmission and disease manifestations. Interventions that target spread of virus between epidermal cells in a single ulcer, and to new regions of the genital tract, will be of value in controlling HSV-2 infection. These factors may explain why HSV-2 reactivation and/or coinfection with other strain in the presence of HSV-2 IgG seropositivity.

Pregnancy is a risk factor that influence development of bad obstetric outcome due to infection of pregnant women with remote/ latent Toxoplasma $(\mathrm{OR}=2.32$, $\mathrm{P}=<0.0001)$, current rubella $(\mathrm{OR}=19.229, \mathrm{P}=0.004)$, current $\mathrm{CMV}(\mathrm{OR}=3.15, \mathrm{P}=0.004)$ and remote/latent CMV $(\mathrm{OR}=3.14, \mathrm{P}=0.01)$ infections. The present study demonstrates a high vulnerability of the pregnant women to T. gondii infection and suggests that the public health policy should include primary and secondary prevention for all pregnant women at high risk. The benefits resulting from lower incidence of congenital toxoplasmosis with the adoption of these measures justify the costs, because it guarantees good quality of life to infected fetuses. ${ }^{24}$ Previous pregnancy showed to the greatest risk factor to toxoplasmosis infection in studies reported for Brazil. ${ }^{24}$

The presence of gestation increased the risk to acquire toxoplasmosis in 2.3, for rubella 19.2, for CMV 3.1 times higher for pregnant women in general population. During pregnancy, especially at the end, there are alterations in the mothers $\mathrm{T}$ lymphocytes subpopulations, with $\mathrm{CD}_{4}$ lymphocytes decreasing and $\mathrm{CD}_{8}$ lymphocytes increasing, the natural killer cells also have decreased immune functions of neutrophils, monocytes, and macrophages. ${ }^{25}$ The phagocytic function and the chemotaxis of polymorphonuclear neutrophils are depleted in women between the 30th and 34th weeks of gestation, which would explain the higher vulnerability to the invasion of $T$. gondii during the third trimester of pregnancy.25 To the best of our knowledge, although there are many studies about risk factors to acquire TORCH and its effects on pregnancy, only the present study and another reported one concerning toxoplasmosis, on the risk of pregnancy itself to acquire the TORCH agents infection have been made. Thus, we conclude that pregnancy is a risk factor for TORCH infections, and this was due to immunological alterations that occur in pregnant women, which can provoke immune suppression. ${ }^{24,25}$

\section{CONCLUSIONS}

In conclusion, this study indicated that Toxoplasma gondii IgM, rubella IgM, rubella IgG, CMV IgM, HSV$2 \mathrm{IgG}$ and animal exposure were risk factors that lead to BOH development. Mother education was a significant protective factor that reduce development of BOH. In addition, pregnancy was a risk factor for toxoplasma, rubella and CMV infections, while crowding index was risk factor rubella and HSV-2 infections. Furthermore, residence was risk factor for toxoplasma and CMV infections, while occupation was $\mathrm{v}$ risk factor for rubella infection.

CONFLICT OF INTEREST: None to declare.

FINALCIAL INTEREST: None to declare.

\section{REFERENCES}

1. Karabulut A, Polat Y, Turk M, Balci YI. Evaluation of rubella, T. gondii, cytomegalovirus seroprevalences among pregnant women in Denizli province. Turk J Med Sci 2011;41:159-164. 
2. Kumari N, Morris N, Dutta R. Is screening of TORCH worthwhile in women with bad obstetric history: an observation from eastern Nepal. J Health Pop Nutr 2011; 29:77-80.

3. Surpam RB, Kamlakar UP, Khadse RK, Qazi MS, Jalgaonkar SV. Serological study for TORCH infections in women with bad obstetric history. J Gynec Obstet India 2006;56:41-43.

4. Meka A, Reddy BM. Recurrent spontaneous abortion: an overview of genetic and non- genetic background. Int J Hum Gen 2006;6:109-117.

5. Maldonado YA, Nizet V, Klein JO, Remington JS, Wilson CB. Current concepts of infections of the fetus and newborn infant. In Infectious Diseases of the Fetus and Newborn Infant. $7^{\text {th }}$ ed. 2011.

6. Stegmann BJ, Carey JC,. TORCH infections. Toxoplasmosis, other (syphilis, varicella-zoster, parvovirus B19), Rubella, cytomegalovirus (CMV), and herpes infections. Cur Women's Health Reports 2002;2:253-258.

7. Alsamarai AGM, Aljumaili ZK. Seroepidemiology of Toxoplasma, Rubella, Cytomegalovirus and Herpes Simplex Virus -2 in Women with Bad Obstetric History: A review. Our Dermatol 2013;4. (in press

8. Mohamad K, Kodym P, Maly M, Elrayah I. Assessment of Screening Tests Used to Detect Toxoplasma gondii in Women in Sudan. J Med Diagnost Meth 2012;1:102. doi:10.4172/2168-9784.1000102

9. Biswas D, Borkakoty B, Mahanta J, Walia K, Saikia L, Akoijam BS. Seroprevalence and risk factors of herpes simplex virus type-2 infection among pregnant women in Northeast India. BMC Infect Dis 2011;11:325-333.

10. Obeid OE. Prevalence of herpes simplex virus types 1 and 2 and associated sociodemographic variables in pregnant women attending King Fahd Hospital of the university. J Fam Commun Med 2007;14:3-7.

11. McLeod R, Remington JS. Toxoplasmosis (Toxoplasma gondii) In: Behrman RE, Kliegman RM, Jenson HB, editors. Nelson Textbook of pediatrics. $16^{\text {th }}$ ed. Philadelphia: PA: WB Saunders; 2000;1054-1062.

12. Sarkar MD, Anuradhae B, Sharma N, Roy NR. Seropositivity of Toxoplasmosis in antenatal women with bad obstetric history in a tertiary-care hospital of Andhra Pradesh, India. J Health Pop Nutr 2012;30:87-92

13. Page A, Taylor R, Richters J, et al. Upstairs and downstairs: socioeconomic and gender interactions in herpes virus type 2 seroprevalence in Australia. Sex Trans Dis 2009;36:344-349.

14. Schoub BD. Rubella in South Africa: An impending Greek Tragedy? South African Med J 2009;99:515-519.

15. Sadik MS, Fatima H, Jamil K, Patil C. Study of TORCH profile in patients with bad obstetric history. Biol Med 2012;4:95-101.

16. Jahromi, AS, Kazemi, A, Manshoori, G, Madani, A, Moosavy, SH, Seddigh, B. Seroprevalence of rubella virus in women with spontaneous abortion. Am J Infect Dis 2011;7:16-19.

17. Langiano E, Ferrara M, Lanni L, Atrei P, Martellucci G, De Vito E. Rubella seroprevalence in childbearing age women: a cross sectional study in the province of Frosinone, central southern Italy. Italian J Pub Health 2009;6:194-201.

18. Alsamarai AGM, Potter CW. Type incidence of HSV in clinical isolates from patients with herpes genitalis. Ann Saudi Med 1990;10:156-160.

19. Alsamarai AGM, Shareef AA, Kinghorn G, Potter CW. sequential genital infections with herpes simplex virus types 1 and 2. Genitourin Med 1989;65:39-41.

20. Mark KE, Wald A, Magaret AS, et al. Rapidly cleared episodes of herpes simplex virus reactivation in immunocompetent adults. J Infect Dis 2008;198:11411149 .

21. Schiffer JT, Swan D, Al Sallaq R, et al. Rapid localized spread and immunologic containment define Herpes simplex virus- 2 reactivation in the human genital tract. eLife 2013;2:e00288. DOI: 10.7554/eLife.00288

22 . Ribeiro RM, Qin L, Chavez LL, Li D, Self SG, Perelson AS. Estimation of the initial viral growth rate and basic reproductive number during acute HIV-1 infection. J Virol 2010;84:6096-6102.

23. Farnsworth A, Johnson DC. Herpes simplex virus gE/gI must accumulate in the trans-Golgi network at early times and then redistribute to cell junctions to promote cell-cell spread. J Virol 2006; 80:3167-3179.

24. Avelino MM, Campos Jr D, Parada JCB, Castro AM. Pregnancy as a risk factor for acute toxoplasmosis Seroconversion. Eur J Obstet Gynecol Reprod Biol 2003;108:19-24.

25. Crouch SPM, Crocker IO, Fletcher J. The effect of pregnancy on polymorphonuclear leukocyte function. J Immunol 1995;155:5436-5443

\section{Citing this article}

Aljumaili ZKM, Alsamarai AM. Risk factors for bad obstetric history in Kirkuk women, Iraq. Int J Infect Microbiol 2013;2(3):70-77. 